\title{
ЗНАЧЕННЯ КОМУНІКАТИВНОЇ КОМПЕТЕНТНОСТІ У ПРОФЕСІЙНОМУ СТАНОВЛЕННІ МАЙБУТНІХ ПСИХОЛОГІВ
}

УДК: 159.946 .3

\section{Пузъ Ірина Володимирівна}

Кандидат психологічних наук, дочент, дочент кафедри психології Донеиького начіонального університету імені Василя Стуса, м. Вінниия (Украӥна)

\section{Шевченко Оксана Михайлівна}

Магістрант спеціальності «Психологія» Донецького національного університету імені Василя Стуса, м. Вінниця (Украӥна)

\begin{abstract}
Аннотация. Стаття присвячена розкриттю значення комунікативної компетентності y професійному становленні майбутніх психологів. Проаналізовано особливості професійного становлення майбутніх психологів на етапі професійного навчання, розкрито поняття комунікативної компетентності, висвітлено особливості прояву комунікативної компетентності у професійній діяльності психологів, визначено умови формування комунікативної компетентності y майбутніх психологів під час професійного становлення. Проведено емпіричне дослідження особливостей розвитку комунікативної компетентності у майбутніх психологів. Встановлено, щзо студенти-психологи старших курсів мають більш високий рівень комунікативної компетентності у порівнянні зі студентами молодших курсів.
\end{abstract}

Ключевые слова: професійне становлення, професійне навчання, майбутні психологи, комунікативна компетентність, комунікативні знання, вміння та навички.

Постановка проблеми. У реаліях сьогодення все більшого значення для фахівця будь-якої галузі набуває здатність бути суб'єктом свого професійного розвитку та самостійно знаходити ефективні шляхи вирішення різного роду соціально та професійно значущих проблем в умовах мінливої дійсності.
Ефективність професійного становлення фахівців визначається не тільки наявністю в них необхідних професійних знань, вмінь та навичок, але й наявністю спеціальних здібностей та особистісних властивостей, що забезпечують гнучкість та динамізм професійної поведінки, креативність у професійній діяльності, 
самостійність у пошуку та засвоєнні нової інформації і нового професійного досвіду. Важливим та необхідним для сучасних фахівців $\epsilon$ здатність до прийняття адекватних рішень у так званих «нестандартних» ситуаціях, в умовах дефіциту часу або інформації, наявність навичок оптимальної взаємодії 3 іншими учасниками виробничого процесу під час виконання будь-яких завдань професійної діяльності [2].

Загальновідомим $є$ той факт, що одним iз найбільш важливих та значущих етапів у процесі професійного становлення особистості як майбутнього фахівця виступає період навчання у закладі вищої освіти. Слід зазначити, що саме у ході навчання відбувається так зване первинне «опанування» професії, визначається життєва і світоглядна позиція молодої людини. Саме тому, важливим на цьому етапі є створення таких умов навчально-виховного процесу, які б відповідали особливостям й закономірностям не тільки особистісного розвитку студента, але і його професійного становлення як фахівця.

Провідним завданням професійного становлення майбутніх психологів на етапі навчання $є$ формування професійної спрямованості, сутність якої проявляється у їх спрямованості на успішне оволодіння навчальною програмою, на ефективне використання отриманих професійних знань, умінь та навичок, а також у прагненні розвивати ті здібності, які дозволяють не тільки успішно оволодіти про- фесією, але й надалі вдосконалюватися у межах обраної професійної діяльності. Під час професійного становлення психолога має відбуватися не тільки оволодіння професійними знаннями, вміннями та навичками, але і його особистісне і духовне зростання. Самоаналіз досвіду роботи і досвіду спілкування з іншою людиною повинні виступати стимулом не тільки для удосконалення різноманітних професійних компетенцій, але й виступати підгрунтям для саморозвитку, що є головною запорукою успішності майбутньої професійної діяльності психолога.

Одним із необхідних чинників становлення майбутніх психологів як професіоналів $\epsilon$ формування комунікативної компетентності. Загальновідомо, що специфіка означеної професійної діяльності висуває до особистості студентів цілу низку вимог щодо розвитку різного роду особистісних якостей та здібностей, серед яких особливого значення набуває формування комунікативних здібностей, зокрема оволодіння вербальними і невербальними засобами спілкування, вміння вступати у контакт. На думку таких дослідників, як Ю. Б. Алешина, Р. С. Абрамова, Р. Кочюнас, комунікативна компетентність виступає «серцевиною професіоналізму особистості психолога», тому що спілкування 3 людьми становить сутність означеної сфери професійної діяльності [9]. Слід зазначити, що саме сформованість комунікативної компетентності дає можливість психологу успішно вступа- 
ти у різного роду контакти для вирішення різноманітних комунікативних задач, зокрема передачі інформації, встановлення та підтримки контактів, організації та надання психологічної допомоги тощо. Отже, виходячи з вищевикладеного, стає зрозумілим, що питання, які пов'язані із дослідженням проблеми формування комунікативної компетентності у майбутніх психологів набувають особливого практичного значення, оскільки саме від рівня сформованості даного утворення залежить ефективність не тільки подальшого професійного, але й особистісного розвитку психолога.

Аналіз останніх досліджень і публікацій. Різні аспекти проблеми професійного становлення майбутніх психологів висвітлюються у роботах таких вітчизняних вчених, як Г. Балл, О. Бондаренко, С. Васьківська, Ж. Вірна, П. Горностай, Т. Говорун, Є. Заїка, О. Іванова, О. Кокун, Н. Коломінський, С. Максименко, В. Панок, Ю. Приходько, Л. Уманець, Н. Шевченко, Н. Чепелєва, Т. Яценко та ін. Проблема комунікативної компетентності як ефективного психологічного інструмента суб'єкта комунікації висвітлюється у роботах К. О. АльбухановоїСлавської, Г. М. Андреєвої, О. О. Бодальова, Л. П. Буєвої, О. М. Леонтьєва, М. С. Кагана, С. Д. Максименка, Б. Д. Паригіна та ін. Питання професійного спілкування і комунікативної компетентності психологів представлені у роботах таких вчених, як Г. О. Балл, М. М. Заброцький, В. О. Кан-Калік,
Я. Л. Коломінський, О. М. Корніяка, С. О. Мусатов, Т. С. Яценко та ін. Чинники розвитку комунікативних вмінь особистості досліджувалися такими науковцями, як Ю. М. Смельянов, Л. А. Петровська, С. В. Петрушин та ін.

Mema cmammi: розкрити значення комунікативної компетентності у професійному становленні майбутніх психологів.

\section{Виклад основного матеріалу дослі-}

джсення. Професійне становлення майбутніх психологів починається 3 моменту вступу до закладу вищої освіти, визначається складністю за своєю психологічною структурою, та будучи багатоаспектним процесом активної взаємодії студентів з навчально-професійним середовищем, має на меті досягнення між ними таких взаємовідносин, які мають забезпечувати не тільки професійний, але й особистісний розвиток майбутніх фахівців [7]. На думку О. Ф. Бондаренка та В. Г. Панка, професійна підготовка студентів-психологів має відбуватися за такими напрямами, як поглиблення професійної спрямованості та розвиток необхідних здібностей; удосконалення психічних процесів, станів, досвіду; розвиток почуття обов'язку та відповідальності за успіх майбутньої професійної діяльності; зростання загальної зрілості і стійкості особистості; формування професійної самостійності і готовності до майбутньої практичної професійної діяльності [1].

Необхідними умовами формування у 
студентів-психологів готовності до професійної діяльності, що власне і виступає одним із головних аспектів їх професійного становлення, $є$ успішне проходження ними низки стадій під час професійного навчання, а саме: адаптації, інтенсифікації, ідентифікації [5]. Так, на стадії адаптації, яка охоплює першій рік навчання, відбувається активне пристосування студентів до умов i змісту навчальнопрофесійного процесу, відбувається засвоєння ними нової соціальної ролі, налагодження міжособистісних відносин один з одним. Важливе значення на цій стадії мають як суб'єктивні (мотиви вибору професії психолога, установки на навчання, індивідуально-психологічні особливості особистості та ін.), так і об'єктивні чинники (форми та методи навчання, спрямованість академічної групи та ін.). Психологічним критерієм успішного проходження цієї стадії $є$ адаптованість до вимог навчального середовища, емоційна стабільність, особистісне самовизначення та вироблення нового стилю життєдіяльності, що безперечно сприяє самоосвіті, самоорганізації, мотивації до навчання, готовності до опанування новими знаннями. На другій стадії професійної підготовки - стадії інтенсифікації, яка триває протягом другого-третього курсів навчання, відбувається розвиток загальних і спеціальних здібностей студентів, інтелекту, емоційно-вольової регуляції, відповідальності за своє професійне та особистісне становлення. Провідною діяльністю на цій стадії виступає науково- пізнавальна. Конструктивне проходження цієї стадії визначається за такими показниками, як особистісний і інтелектуальний розвиток студентів, критичність та гнучкість мислення, адекватний рівень самоповаги, позитивна внутрішня мотивація до навчально-професійної діяльності. На завершальній стадії - стадії ідентифікації передбачається формування у студентів професійної ідентичності, готовності до майбутньої професійної діяльності психолога, головними показниками якої $є$ ототожнення студентів 3 обраною професією, їхнє професійне самовизначення, наявність в них адекватної самооцінки власного Я, незалежність їхніх суджень. Про неготовність випускників-психологів до виконання професійної діяльності свідчить, перш за все, неузгодженість структурних компонентів «Яконцепції» (Я-реального та Я-ідеального), суперечливе ставлення до себе, як до особистості та фахівця, розвиток низки особистісних деструкцій.

Важливим під час професійного становлення особистості майбутнього психолога у ході навчання є формування осмисленого ставлення до себе у контексті професійнонавчальної діяльності та до діяльності у цілісному контексті життя [4]. Слід зазначити, що на сучасному етапі розвитку психологічної науки та практики професійне становлення студентів-психологів вимагає від них складної та напруженої творчої роботи, спрямованої на глибоке самопізнання та розвиток власної осо- 
бистості. Успішність професійного становлення майбутніх психологів залежить від багатьох чинників, найбільш важливим із яких виступає рівень розвитку професійної свідомості та самосвідомості, оскільки саме на підставі даних психічних утворень відбувається формування професійно важливих якостей та професійного мислення, що сприяє формуванню готовності до професійної діяльності. Нозвиток професійної самосвідомості психолога є процесом і результатом усвідомлення ним самого себе в навчально-професійній сфері, цілеспрямоване регулювання на цій основі своєї поведінки та діяльності в цілому [5].

Отже, узагальнюючи вищевикладене, можна зробити висновок, що процес професійного становлення майбутніх психологів представляє собою досить складний та тривалий процес, ефективність якого залежить від різного роду чинників. Важливим під час професійного становлення майбутніх психологів $€$ формування комунікативної компетентності, оскільки означена сфера професійної діяльності належить саме до тих видів праці, де спілкування перетворюється на професійно значущу, суттєву сторону, особливості якої визначають ефективність професійної діяльності.

Аналіз наукової літератури свідчить про те, що не зважаючи на широке вживання поняття «комунікативної компетентності», на сьогодні й досі відсутня однозначне визначен- ня цього терміну. Так, найчастіше комунікативну компетентність розглядають як здатність встановлювати та підтримувати необхідні контакти $з$ людьми. Комунікативна компетентність визначається як певна сукупність знань, вмінь та навичок, що забезпечують ефективний перебіг комунікативного процесу [8]. Комунікативна компетентність сприяє досягненню бажаних результатів під час спілкування.

На думку В. П. Захарова та Н. Ю. Хрящової, основними факторами прояву комунікативної компетентності у спілкуванні є: знання в галузі психології особистості, групи, спілкування; вміння та навички спілкування; корекція і розвиток установок, необхідних для успішного спілкування; здатність адекватно і повно сприймати і оцінювати себе та інших людей, а також взаємини, що виникають між людьми; корекція та розвиток системи ставлень особистості, до проблем і ситуацій, які виникають у процесі спілкування [10].

Як вважає I. О. Зимняя, комунікативна компетентність - це здатність особистості здійснювати мовленнєву діяльність, реалізуючи мовленнєву поведінку, адекватну за цілями, засобами й способами, різними завданнями й ситуаціями спілкування [9].

Комунікативну компетентність, на думку Ю. М. Жукова, слід розглядати не тільки як здатність встановлювати і підтримувати необхідні контакти з іншими людьми, але як 
сукупність відповідних знань і умінь, що забезпечує ефективний перебіг комунікативного процесу. Виходячи з цього, головною особливістю комунікативної компетентності є вміння знаходити спільну мову з людьми, володіти навичками ефективного спілкування з учасниками комунікативного акту [10].

У дослідженнях О. М. Корніяки комунікативна компетентність визначається як складно організоване, внутрішнє суперечливе поєднання комунікативних знань і вмінь, що відображають цілі та результати здійснюваної суб'єктом спілкування комунікативної діяльності [6].

На думку М. М. Обозова, комунікативну компетентність можна розглядати у двох аспектах: по-перше, як орієнтованість особистості в різних ситуаціях спілкування, що базується на знаннях і чуттєвому досвіді; по-друге, як здатність ефективно взаємодіяти з оточуючими людьми завдяки розумінню самого себе й інших людей в умовах постійної зміни їх психічних станів, міжособистісних взаємин та соціальної ситуації [10].

Будучи складним особистісним утворенням, комунікативна компетентність має певну структуру. 3 позиції системного підходу у структурі комунікативної компетентності прийнято виокремлювати чотири основні компоненти, які перебувають у нерозривній єдності між собою: когнітивний (пізнавальний), комунікативно-мовленнєвий, соціальноперцептивний та інтерактивний. Пропонуємо коротко розглянути їх зміст. Так, зміст когнітивного компоненту комунікативної компетентності визначають знання з галузі психології спілкування; здатність до самопізнання і саморозуміння людиною особливостей своїх комунікативних характеристик; готовність до комунікативно-розумової діяльності. Зміст комунікативно-мовленнєвого компоненту представлений здатністю комуніканта доречно застосовувати вербальні і невербальні засоби для виконання цілого ряду комунікативних функцій професійної діяльності, а також володіння комунікантом граматичним кодом (словниковий запас, правила правопису та вимови, словотворення та побудова речень). До змісту соціально-перцептивного компонента відноситься здатність за зовнішніми ознаками розуміти психологічну сутність партнера зі спілкування, спроможність створити його цілісний образ з метою правильної організації власних комунікативних дій; володіння внутрішніми засобами регуляції комунікативних дій (емпатія, рефлексія); здатність до регулювання емоційного стану у взаємодії. Зміст інтерактивного компоненту визначає здатність до продуктивного професійного і міжособистісного спілкування, що передбачає володіння суб'єктом стратегіями психологічного впливу та конструктивними способами поведінки у взаємодії; спроможність адаптувати індивідуальні комунікативні характеристики до вимог професійного спілкування. 
Таким чином, узагальнюючи вищевикладене, стає зрозумілим, що комунікативна компетентність $є$ складним системноструктурним утворенням, складовими якого $є$ відповідні комунікативні здібності, комунікативні знання, вміння та навички.

Для ефективного виконання завдань професійної діяльності сформована комунікативна компетентність має складатися з наступних здібностей:

- вміти давати соціально-психологічний прогноз комунікативній ситуації, в якій передбачається спілкування;

- $\quad$ програмувати процес спілкування, враховуючи своєрідність комунікативної ситуації;

- здійснювати соціально-психологічне управління процесами спілкування;

- $\quad$ будувати контакт на різній психологічній дистанції;

- динамічність та адекватність у зміні психологічних позицій [10].

Серед основних комунікативних навичок та вмінь психологів прийнято виокремлювати такі, як: активне слухання; встановлення зворотного зв'язку; вміння тримати клієнта на відстані, ухилятися від емоційної близькості; розвинені емпатійні здібності; вміння використовувати стратегії, які сприяють змінам поведінки клієнта; вміння концентрувати увагу на певних об'єктах та явищах, відображуючи їх достатньо об'єктивно та адекватно.
Важливими комунікативними якостями психолога виступають: схильність до спілкування з людьми, вміння ефективно вирішувати конфлікти, володіння вербальними та невербальними засобами спілкування, логічна та чітка мова, ввічливість, почуття гумору.

На думку Н. І. Пов'якель, ефективне вирішення майбутнім психологом професійних завдань залежить від наявності та рівня сформованості цілої низки професійно важливих особистісних рис та якостей, серед яких виокремлюється здатність майбутнього фахівця в галузі психології до діалогу та партнерства у створенні професійних відносин і регуляції професійного мислення, а також наявності професійно важливих соціальнокогнітивних і комунікативних здібностей [8].

У складі комунікативної компетентності майбутніх психологів, згідно 3 позицією О. М. Корніяки, слід розрізняти такі компетентності, як комунікативно-мовленнєва, інтерактивна та перцептивна, за допомогою яких, суб'єкт спілкування здійснює у процесі комунікативної діяльності обмін інформацісю (розуміння її смислу та висловлення думок), вироблення спільної стратегії взаємодії та встановлення взаємин, сприймання та розуміння партнера зі спілкування [6].

Психологічна готовність майбутнього психолога до взаємодії містить когнітивну, емоційно-вольову та поведінкову складові. Так, зміст когнітивної складової відображає вміння бути уважним до іншого, адекватно 
сприймати і відображати комунікативну інформацію, адекватно бачити проблему, гнучкість і неригідність мислення, здатність до рефлексії. Емоційно-вольова складова містить зацікавленість, позитивну мотивацію, емпатійне реагування тощо. Поведінкова складова містить у собі адекватність поведінкових реакцій, відсутність проекцій і конфліктогенів типу зневаги, презирства, образ тощо [9].

На процес формування комунікативної компетентності майбутніх психологів можуть впливати різні індивідуально-психологічні та соціально-психологічні чинники. Вони зумовлюються вищою нервовою діяльністю, потребами, інтересами, мотивацією, здібностями, індивідуально-психологічними характеристиками особистості, умовами життя у соціальному середовищі та соціальним досвідом індивіда, спеціальними методами навчання.

Слід зазначити, що комунікативна компетентність майбутніх психологів не може бути сформована стихійно, необхідним є наявність спеціальної роботи та забезпечення відповідних психологічних умов. Динаміку формування комунікативної компетентності у студентів-психологів визначають дві групи умов, а саме: внутрішні та зовнішні. Так, до внутрішніх умов відносяться: усвідомлення студентами власних особистісних характеристик, які впливають на формування компетентності, проблем, що виникають під час взаємодії з людьми, а також власної поведінки у різного роду комунікативних ситуаціях; співвід- ношення студентами-психологами власних особистісних та професійних позицій в навчально-професійній діяльності. Зовнішні умови передбачають: включення студентів у квазіпрофесійну діяльність; здійснення психологічного супроводу формування комунікативної компетентності.

Важливим на етапі професійного навчання майбутніх психологів $\epsilon$ не тільки вивчення низки нормативних дисциплін («Соціальна психологія», «Психологія спілкування», «Конфліктологія з основами психології малих груп», «Психологічне консультування», «Психотерапія та психокорекція»), але i впровадження різного роду спецкурсів та соціально-психологічних тренінгів, які мають бути спрямовані на підвищення рівня комунікативних знань та здібностей. В цілому можна виокремити наступні психолого-педагогічні умови та чинники, які сприяють розвитку комунікативної компетентності у студентівпсихологів: 1) застосування особистісноорієнтованого підходу до навчальнопізнавальної діяльності, який передбачає визнання особистості студента як найвищої цінності; 2) залучення студентів до активної навчально-пізнавальної діяльності; 3) формування позитивної професійної «Я-концепції»; 4) усвідомлення студентами нерозривного взаємозв'язку та взаємозалежності між рівнем розвитку професійно-комунікативних якостей та ефективністю професійної комунікативної діяльності; 5) навчально-методичне забезпе- 
чення розвитку професійної комунікативної компетентності; 6) формування у студентів готовності та бажання здобувати професійні знання, вміння і навички [3].

Отже, процес формування комунікативної компетентності майбутніх психологів під час професійного становлення на етапі професійного навчання потребує реалізації конкретних завдань, зокрема оволодіння теорією професійного спілкування, пізнання його структури, стилів, моральних принципів, входження у технологію даного процесу, формування у результаті цього професійно-комунікативних умінь та навичок, розвитку гуманістичного мислення, усвідомлення цінностей професії психолога, активізації мотиваційної сфери на здобуття професії психолога [8].

Відповідно до мети даної роботи нами було проведено експериментальне дослідження, спрямоване на виявлення значення комунікативної компетентності у професійному становленні майбутніх психологів. Дослідження проводилося на базі навчальної лабораторії кафедри психології Донецького національного університету імені Василя Стуса. Вибірку дослідження склали студенти СО «Бакалавр» та СО «Магістр» спеціальності «Психологія». Загальна кількість досліджуваних 61 студент, 3 них: 8 студентів I курсу, 18 - II курсу, 17 III курсу, 10 - IV курсу, 8 - магістранти першого року навчання.

У якості психодіагностичного інструментарію нами використовувалися наступні методи та методики: тест «Уміння слухати» та тест «Уміння викладати свої думки»; методика «Діагностика самоконтролю у спілкуванні» М. Снайдера; методика «Вивчення комунікативних i організаторських схильностей» (В. В. Синявський і Б. О. Федоришина); методика «Діагностика рівня емпатійних здібностей» В. В. Бойко.

Аналіз результатів емпіричного дослідження свідчить про наступні характерні відмінності комунікативної компетентності у студентів-психологів. Так, оцінка вміння слухати та вміння викладати свої думки свідчить про те, що високий рівень означених вмінь було діагностовано у 12,5\% студентів I курсу; 27,7\% - II курсу; 41,2\% - III курсу; 40,0\% IVкурсу та 37,5\% - магістрантів. Низький рівень, який свідчить про несформованість даних вмінь, що було виявлено серед 50,0\% студентів I курсу; 38,8\% - II курсу; 29,4\% - III курсу; 30,0\% - IV курсу та 12,5\% - магістрантів.

Високий рівень комунікативного контролю, який свідчить про легкість входження у будь-яку роль, здатність швидко реагувати на зміну ситуації, добре відчувати і навіть передбачати враження про себе інших людей, було діагностовано у 25,0\% студентів I курсу, 33,3\% - II курсу, 35,3\% - III курсу, 30,0\% - IV курсу, 50,0\% - магістрантів. Низький комунікативний контроль, який визначається нездатністю змінюватися відповідно до умов ситуації, збереженням безпосередності і відкритос- 
ті, було характерно для 50,0\% студентів I курсу, 44,4\% - II курсу, 29,4\% - III курсу, 20,0\% IV курсу, 12,5\% -магістрантів.

Вивчення комунікативних схильностей показало, що дуже високий рівень був притаманний для 11,1\% студентів II курсу, 11,7\% III курсу, 20,0\% - 4 курсу, 25,0\% - магістрантів; високий рівень у 12,5\% студентів I курсу, 16,6\% - II курсу, 29,4\% - III курсу, 30,0\% - IV курсу, 37,5\% - магістрантів; середній рівень у 25,0\% студентів I курсу, 33,3\% - II курсу,47,1\% - III курсу, 30,0\% - IVкурсу, 25,0\% магістрантів. Рівень нижчий від середнього діагностовано у $37,5 \%$ студентів I курсу, 22,2\% - II курсу, 17,6\% - III курсу, 20,0\% - IV курсу, 12,5\% - магістрантів; низький рівень у $25,0 \%$ студентів I курсу та $16,6 \%$ студентів II курсу.

Результати діагностики рівня емпатійних здібностей свідчать про те, що високий рівень розвитку емпатії було виявлено лише у 12,5\% студентів I курсу, 16,6\% - II курсу, 23,5\% - III курсу, 30,0\% - IV курсу та 37,5\% студентів, які навчаються у магістратурі. Середній рівень було виявлено у $25,0 \%$ студентів I курсу, 38,8\% - II курсу, 41,2\% - III курсу, 50,0\% - IV курсу, 50,0\% - магістрантів. Низький рівень був характерним для 62,5\% студентів I курсу, 38,8\% - II курсу, 35,3\% - III курсу, $25,0 \%$ - IV курсу та 12,5\% - магістрантів.

Представлений аналіз отриманих даних дозволяє нам виокремити три рівні сформованості комунікативної компетентності у дослі- джуваних студентів: високий, середній та низький. Так, у $31,1 \%$ студентів було виявлено високий рівень сформованості комунікативної компетентності, що вказує на наявність знань про ситуативні норми спілкування, позитивне ставлення до співрозмовника, добре розвинені комунікативні та організаторські здібності, здатність до емпатійного реагування, вміння співпереживати, сформовані вміння говорити i вміння слухати, здатність досягати взаєморозуміння у професійній і міжособистісній взаємодії.

У 26,2\% досліджуваних було виявлено середній рівень розвитку комунікативної компетентності, який характеризується певною нерівномірністю розвитку її основних параметрів. Слід зазначити, що у таких студентів сформовано вміння говорити, проте недостатньо розвинене вміння слухати, при середньому рівні самоконтролю у спілкуванні. Вони мають уявлення про значення емпатії у професійній діяльності психологів, проте не завжди здатні до емпатійного реагування під час міжособистісного та професійного спілкування.

Характерним для 42,6\% студентів є наявність низького рівня розвитку комунікативної компетентності, що вказує на недостатню сформованість комунікативних знань, труднощі у встановленні комунікативних контактів 3 людьми, низький рівень самоконтролю у спілкуванні, нездатність до прояву емпатії, невміння слухати співрозмовника.

Висновки. Такими чином, узагальнюю- 
чи вищевикладене, можна зробити висновок, що комунікативна компетентність являє собою складну інтегральну характеристику особистості майбутнього психолога. Формування комунікативної компетентності майбутніх психологів на етапі професійного навчання передбачає не тільки засвоєння сукупності відповідних комунікативних знань, вмінь та навичок, але й готовність їх адекватно та ефективно використовувати під час виконання професійних завдань. Отримані результати емпіричного дослідження свідчать про недостатній рівень розвитку комунікативної компетентності у майбутніх психологів, що може бути обумовлено цілою низкою чинників, зокрема роком навчання, індивідуальнопсихологічними особливостями особистості студентів тощо. Враховуючи значущість комунікативної компетентності у професійній діяльності психолога, доцільним $€$ впровадження у процес навчання різноманітних соціально-психологічних тренінгів, які сприятимуть засвоєнню студентами комунікативних вмінь, підвищенню рівня їх емоційній чутливості, емпатії, створенню сприятливої соціально-психологічної атмосфери у академічній групі, що безумовно бути мати важливе значення під час професійного становлення майбутніх психологів.

\section{Перспективи подальших розвідок по-} лягають у розробці та впровадженні у навчально-виховний процес програми психологічного супроводу розвитку комунікативної компетентності у майбутніх психологів з обов'язковим урахуванням чинників та умов, які детермінують формування даного інтегрального утворення.

\section{Перелік використаних джерел:}

1. Адамська 3. Суб'єктність у системі професійно значущих якостей особистості майбутнього психолога/ 3. Адамська// Психологія особистості. - 2011. - № 1(2). - C. 51-58.

2. Бацилєва О., Пузь I. В. Проблема формування готовності до професійної діяльності у майбутніх психологів / О. В. Бацилєва, І. В. Пузь // Психологічна освіта в Україні: традиції, сучасність та перспективи, 21-22 квітня 2017 року : Матеріали Всеукраїнської науковопрактичної конференції з нагоди святкування 50-річчя від початку фахової підготовки психологів у КНУ імені Tараса Шевченка та Дня психолога / За ред. I. В. Данилюка. - К. : Логос, 2017. - С. 21-23.

3. Іванова I. Ф. Вплив рівня розвитку комунікативних здібностей на формування професійної спрямованості студентів-психологів / І. Ф. Іванова // Збірник наукових праць. Психологічні науки. - 2013. - Т.2. Вип.10(91). C. 121-125. - Режим доступу: http://en.mdu.edu.ua/ spaw2/uploads/files/26_19.pdf

4. Кокун О. М. Психологія професійного становлення сучасного фахівця: Монографія. - К.: ДП «Інформ.аналіт. агенство», 2012. - 200 с.

5. Корень T. О. Модель професійного розвитку майбутнього психолога у вищому навчальному закладі/ Т. О. Корень// [Електронний ресурс] - Режим доступу http://virtkafedra.ucoz.ua/el_gurnal/pages/vyp4/psihologia/ koren.pdf

6. Корніяка О. М. Вивчення розвитку комунікативної компетентності студентів / О. М. Корніяка // Психолінгвістика: Зб. наук. праць ДВНЗ «ПереяславХмельницький державний педагогічний університет 
імені Григорія Сковороди». - ПереяславХмельницький: ПП «СКД», 2009. - Вип.3. - С. 60 - 69.

7. Крикля К. П. Психологічні особливості професійного становлення майбутнього психолога в умовах сучасного суспільства / К. П. Крикля// Науковий вісних Львівського державного університету внутрішніх справ (Серія психологічна). - 2012. - №2(1). - С.409-417.

8. Низовеиь О. А. Розвиток комунікативної компетентності у процесі професійної підготовки майбутніх психологів /О. А. Низовець// Актуальні проблеми професійної діяльності молодих спеціалістів. - 2007. - №3 (5). - C. 355-362.

9. Соловьева О. В., Аникеева Ю. В. Комуникативная компетентность психолога: подходы и концепции / О. В. Соловьева, Ю. В. Аникеева // Вектор науки ТГУ. - 2012. - № 1(8). - С. 267-270.

10. Черезова I. O. Комунікативна компетентність як інтегральна якість особистості / I. О. Черезова // Науковий Вісник Херсонського державного університету. Серія Психологічні науки. - 2014. - Випуск 1., Том 1. C. 103-107.

\section{References (Transsliteration):}

1. Adamska Z. Sub'ektnist u sistemi profesiyno znachuschih yakostey osobistosti maybutnogo psihologa/ Z.Adamska// Psihologiya osobistosti. - 2011. - \# 1(2). - S. 51-58.

2. Batsileva O., Puz I. V. Problema formuvannya gotovnostI do profesIynoyi dIyalnosti u maybutnih psihologiv / O. V. Batsileva, I. V. Puz // Psihologichna osvita v Ukrayini: traditsiyi, suchasnist ta perspektivi, 2122 kvItnya 2017 roku : Materiali Vseukrayinskoyi naukovo -praktichnoyi konferentsIYi z nagodi svyatkuvannya 50rIchchya vId pochatku fahovoYi pIdgotovki psihologIv $u$ KNU ImenI Tarasa Shevchenka ta Dnya psihologa / Za red.

I. V. Danilyuka. - K. : Logos, 2017. - S. 21-23.

3. Ivanova $I$. F. Vpliv rivnya rozvitku komunikativnih zdibnostey na formuvannya profesiynoyi spryamovanosti studentiv-psihologiv / I. F. Ivanova // Zbirnik naukovih prats. Psihologichni nauki. - 2013. - T.2. Vip.10(91). - S. 121-125. - Rezhim dostupu: http://en.mdu.edu.ua/spaw2/ uploads/files/26_19.pdf

4. Kokun O. M. Psihologiya profesiynogo stanovlennya suchasnogo fahivtsya: Monografiya. - K.: DP «Inform.analit. agenstvo», 2012. - $200 \mathrm{~s}$.

5. Koren T. O. Model profesiynogo rozvitku maybutnogo psihologa u vischomu navchalnomu zakladi / T. O. Koren// [Elektronniy resurs] - Rezhim dostupu http:// virtkafedra.ucoz.ua/el_gurnal/pages/vyp4/psihologia/ koren.pdf

6. Korniyaka O. M. Vivchennya rozvitku komunikativnoyi kompetentnosti studentiv / O. M. Korniyaka // Psiholingvistika: Zb. nauk. prats DVNZ «Pereyaslav-Hmelnitskiy derzhavniy pedagogichniy universitet imeni Grigoriya Skovorodi». - Pereyaslav-Hmelnitskiy: PP «SKD», 2009. Vip.3. - S. $60-69$.

7. Kriklya K. P. Psihologichni osoblivosti profesiynogo stanovlennya maybutnogo psihologa $\mathrm{v}$ umovah suchasnogo suspilstva / K. P. Kriklya// Naukoviy visnih Lvivskogo derzhavnogo universitetu vnutrishnIh sprav (Seriya psihologichna). - 2012. - \#2(1). - S.409-417.

8. Nizovets $O$. A. Rozvitok komunikativnoyi kompetentnosti u protsesi profesiynoyi pidgotovki maybutnih psiholoilv / O. A. Nizovets// Aktualni problemi profesiynoyi dIyalnosti molodih spetsialistiv. - 2007. - \#3(5). - S. 355-362.

9. Soloveva O. V., Anikeeva Yu. V. Komunikativnaya kompetentnost psihologa: podhodyi i kontseptsii / O. V. Soloveva, Yu. V. Anikeeva // Vektor nauki TGU. - 2012. \# 1(8). - S. 267-270.

10. Cherezova I. O. Komunikativna kompetentnist yak integralna yakist osobistosti / I. O. Cherezova // Naukoviy Visnik Hersonskogo derzhavnogo universitetu. Seriya Psihologichni nauki. - 2014. - Vipusk 1., Tom 1. - S. 103107.

(C) Пузь I. В., Шевченко О. М. 


\section{Puz Iryna}

PhD in Psychology, Assistant Professor of Department of Psychology of Vasul Stus Donetsk National University, Vinnitsa (Ukraine)

\section{Shevchenko Oksana}

Magistr of Psychology of Vasul Stus Donetsk National University, Vinnitsa (Ukraine)

\section{THE IMPORTANCE OF COMMUNICATIVE COMPETENCE IN THE PROFESSIONAL FORMATION OF FUTURE PSYCHOLOGISTS}

\section{ABSTRACT}

The article is devoted to the study of the importance of communicative competence in the professional activity of future psychologists. It is noted that the effectiveness of the professional development of specialists is determined not only by the availability of the necessary professional knowledge and skills, but also by the availability of special abilities and personal characteristics that provide flexibility and dynamism of professional conduct, independence in finding and mastering the necessary new information and new professional experience . One of the most important and significant stages in the process of professional formation of the individual as a future professional is the period of study in institutions of higher education. It is indicated that it is in the course of vocational training that the socalled primary mastering of the profession takes place, the young man's vital and philosophical position is determined. Therefore, it is important to create such conditions for the educational process, which would correspond to the features and patterns of not only the student's personal development, but also his professional development as a professional.

It is pointed out that the main task of professional development of future psychologists at the stage of vocational training is the formation of a professional orientation, the content of which should be manifested in their striving for successful mastery of the curriculum, the focus on the effective application of the acquired professional knowledge and skills and in striving to develop those abilities, which allow not only to successfully master the profession, but also to improve in it.

The specificity of the professional activity of the psychologist puts forward a number of requirements to the personality of students regarding the development of personal qualities and abilities, among which the special importance is the availability of communicative abilities, in particular effective possession of verbal and nonverbal communication methods, the ability to come into contact, and to show empathic abilities towards the interlocutor.

Based on the analysis of literary data, the concept of communicative competence is disclosed. The features of the manifestation of communicative competence in the professional work of a psychologist are revealed. It was revealed that for the formation of the communicative competence of future psychologists at the stage of professional training, it is necessary to implement a number of tasks and conditions, the most im- 
portant of which are, firstly, mastering the theory of professional communication; second, the entry into technology of the process of professional communication and interaction; third, the formation of communication skills; fourth, awareness of the value of the future profession of a psychologist.

On the basis of theoretical analysis, it was concluded that the formation of communicative competence in future psychologists during professional development at the stage of vocational training presupposes not only the assimilation of the set of necessary professional communicative knowledge and skills, but also their readiness to adequately and effectively use them during the execution of various kind of professional tasks.

The presented results of the empirical research testify to the insufficient level of development of communicative competence among future psychologists, which points to the urgency of introducing a variety of socio-psychological trainings to the learning process aimed at mastering communication skills by students, increasing their emotional sensitivity, empathy, psychological atmosphere in the academic group, which, of course, will be important for the effective professional development of future psychologists.

Key words: professional formation, vocational training, future psychologists, communicative competence, communicative knowledge, skills.

\section{Пузь Ирина Владимировна}

Кандидат психологических наук, дочент, доцент кафедры психологии Донецкого национального университета имени Васыля Стуса, г. Винница (Украина)

\section{Шевченко Оксана Михайловна}

Магистрант специальности «Психология» Донецкого национального университета имени Васыля Стуса, г. Винница (Украина)

\section{ЗНАЧЕНИЕ КОММУНИКАТИВНОЙ КОМПЕТЕНТНОСТИ В ПРОФЕССИОНАЛЬНОМ СТАНОВЛЕНИИ БУДУЩИХ ПСИХОЛОГОВ}

Аннотация. Статья посвящена исследованию значения коммуникативной компетентности в профессиональной деятельности будущих психологов. Отмечено, что эффективность профессионального становления специалистов определяется не только наличием у них необходимых профессиональных знаний, умений и навыков, но и наличием специальных способностей и личностных особенностей, которые обеспечивают гибкость и динамичность профессионального поведения, самостоятельность в поиске и усвоения необходимой новой информации и нового профессионального опыта. Одним из наиболее важных и значимых этапов в процессе профессионального становления личности как будущего профессионала является период обучения в учреждениях высшего образования. Указано, что именно в ходе профессионального обучения происходит так называемое первичное овладение профессией, определяется жизненная и мировоззренческая позиция молодого 
будущего специалиста. Поэтому важным является создание таких условий учебновоспитательного процесса, которые бы соответствовали особенностям и закономерностям не только личностного развития студента, но и его профессионального становления как профессионала.

Указано, что главной задачей профессионального становления будущих психологов на этапе профессиональной подготовки является формирование профессиональной направленности, содержание которой должно проявляться в их стремлении к успешному овладению учебной программой, направленностью на эффективное применение полученных профессиональных знаний, умений и навыков, а также в стремлении развивать те способности, которые позволяют не только успешно овладеть профессией, но и самосовершенствоваться в ней.

Специфика профессиональной деятельности психолога выдвигает к личности студентов целый ряд требований относительно развития личностных качеств и способностей, среди которых особое значение приобретает наличие коммуникативных способностей, в частности эффективное владение вербальными и невербальными способами общения, умение вступать в контакт, проявлять эмпатические способности по отношению к собеседнику.

На основе анализа литературных данных раскрыто понятие коммуникативной ком- петентности. Раскрыто особенности проявления коммуникативной компетентности в профессиональной деятельности психолога. Выявлено, что для формирования коммуникативной компетентности будущих психологов на этапе профессиональной подготовки необходимым является реализация целого ряда задач и условий, наиболее важными из которых являются, во-первых, овладение теорией профессионального общения; во-вторых, вхождение в технологию процесса профессионального общения и взаимодействия; в-третьих, формирование коммуникативных умений и навыков; в-четвертых, осознание ценности будущей профессии психолога.

На основе теоретического анализа сделано вывод о том, что формирование коммуникативной компетентности у будущих психологов во время профессионального становления на этапе профессиональной подготовки предполагает не только усвоение совокупности необходимых профессиональных коммуникативных знаний, умений и навыков, но и готовность их адекватно и эффективно использовать во время выполнения различного рода профессиональных задач. Представленные результаты эмпирического исследования свидетельствуют о недостаточном уровне развития коммуникативной компетентности у будущих психологов, что указывает на актуальность внедрения в процесс обучения разнообразных социально-психологических тренингов, направленных на овладение студентами 
коммуникативными умениями, повышения уровня их эмоциональной чувствительности, способности к эмпатии, созданию благоприятной социально-психологической атмосферы в академической группе, что, безусловно, будет иметь важное значение для эффективного профессионального становления будущих психологов.

Ключевые слова: профессиональное становления, профессиональное обучение, будущие психологи, коммуникативная компетентность, коммуникативные знания, умения и навыки. 